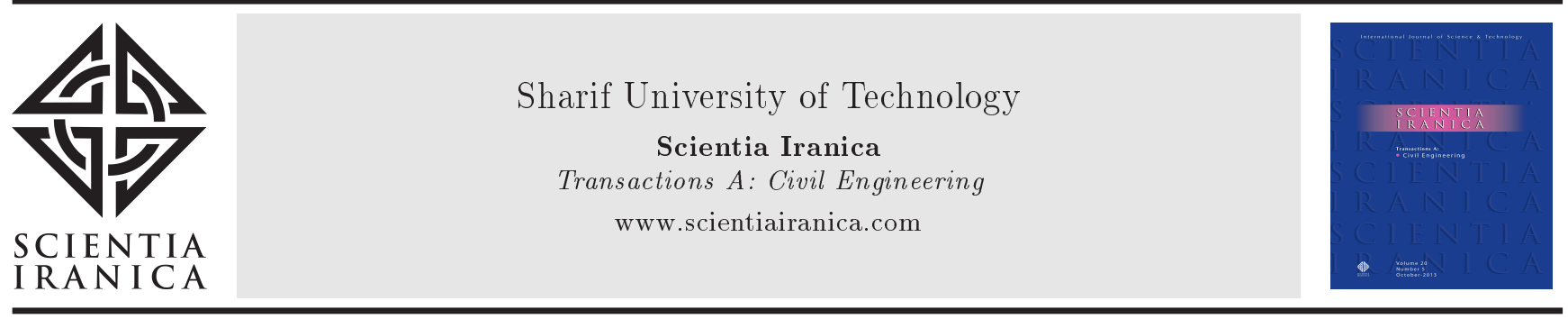

Research Note

\title{
Resiliency via integrated coastal management in Kish Island
}

\author{
A. Pak ${ }^{a, *}$, F. Majd ${ }^{b}$ and M. Mohammadic \\ a. Department of Civil Engineering, Sharif University of Technology, Tehran, Iran. \\ b. Coastal and Port Engineering Section, SPI Consulting Engineers, Tehran, Iran. \\ c. Environmental Management Section, Kish Free Zone Organization, Kish Island, Iran.
}

Received 16 May 2015; received in revised form 15 August 2015; accepted 5 January 2016

\section{KEYWORDS \\ ICZM; \\ Kish Island; \\ Resiliency; \\ Free trade zone; \\ Spatial planning.}

\begin{abstract}
Small islands around the world face various hazards such as sea-water level rise, hurricanes, human activities over pressure, environmental degradation, and pollution. Resiliency is a critical feature that has to be maintained in these sensitive and vulnerable areas. This paper focuses on the importance of Integrated Coastal Management (ICM) in increasing the level of resiliency in small islands. Integrated Coastal Zone Management (ICZM) has been recommended for practice by United Nations 1992 Rio Conference resolution to conserve the valuable natural resources of the coastal areas around the globe and improve their deteriorating environmental conditions. Integrated coastal management plan in small islands should resolve their problems in such a way that sustainable development is guaranteed. Kish is a beautiful small island in the Persian Gulf region, which serves the country as a free trade zone. This article describes its characteristics and problems and also the efforts that have been made for integrated coastal management initiatives in the island to identify the basic problems and provide plans for strengthening the island to manage its current and future problems via acquiring an acceptable level of resiliency.

(C) 2016 Sharif University of Technology. All rights reserved.
\end{abstract}

\section{Introduction}

The world's coastal zone forms a long narrow boundary between land and ocean that is highly valued by human societies. Although coastal zone is relatively small, it is a heterogeneous, dynamic, highly productive, and sensitive area of the earth's surface. Coastal zones occupy less than $15 \%$ of the earth's land surface, yet accommodate between 20.6 to $37 \%$ of the world population in the bands to the nearest $30 \mathrm{~km}$ and $100 \mathrm{~km}$, respectively (estimated at 2002), and roughly $50 \%$, i.e. 3.1 billion people, in the $200 \mathrm{~km}$ range [1].

*. Corresponding author.

E-mail addresses: pak@sharif.edu (A. Pak); majd@sazehpardazi.com (F.Majd); Mary3526@yahoo.com (M. Mohammadi)
With three quarters of the world population expected to reside in the coastal zone by 2025 [1], human activities originating from this small land area will impose an inordinate amount of pressures on the global system.

In addition to the pressures that the coastal zones around the globe are experiencing, small islands usually engage with extra problems. The UN conference on Small Islands Developing States (SIDS) has been held to find common solutions for these vulnerable areas. The conference resolution, called Barbados Program of Action, was the first global endeavor to tackle the problems of these countries [2]. Table 1 shows the inherent features that lead to special vulnerability of small islands [3].

SIDS has increasingly confronted the classic "contradiction between economic progress and environmen- 
Table 1. Inherent features of small islands development states.

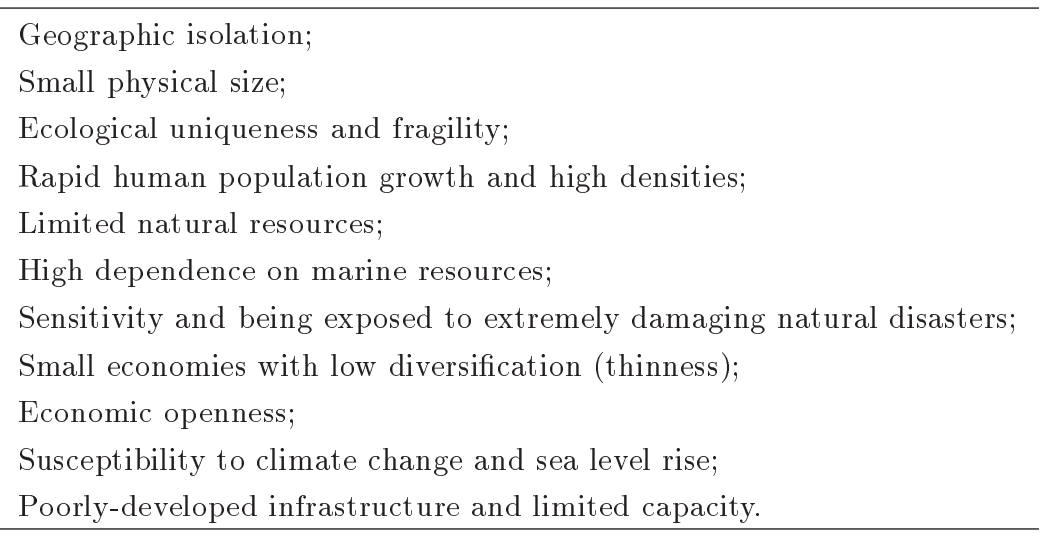

tal degradation". This contradiction is more immediate for small states because of their limited resources and environmental vulnerability. A balance between economy and environment underpins sustainable development. Maintaining resilience is often identified as the main strategy of sustainable development of ecosystems. Resiliency is defined here as the ability to restore the normal situation within a reasonable time period after any undesirable natural incident. It is worth noting that the concept of sustainable development has not gained much success in small islands due to their low level of resiliency against different kinds of natural hazards [4].

In this paper, after providing definition and prospects of ICZM, Iran's efforts regarding ICZM are reviewed. Then, Kish Island and its problems are described. Finally, the spatially oriented ICZM in Kish Island will be presented.

\section{Integrated coastal management}

United Nations' "Environment and Development" conference in Rio in 1992 (Earth Summit) in Chapter 17 of its resolution (agenda 21) has encouraged the countries that have coasts to establish an Integrated Coastal Zone Management (ICZM) Plan to reduce the pressure on their coasts and conserve these valuable areas for future generations. ICZM calls for integration and harmonization of human activities in the coastal areas to prevent the destructive trend that takes place in these areas around the globe. The most important goals of ICZM are:

- Improving the quality of life of human communities which rely on coastal resources;

- Conserving biodiversity;

- Increasing the productivity of coastal ecosystems;

- Maximizing the social benefits derived from coastal areas;

- Minimizing conflict among users and reducing the adverse effects of human activities on the coastal zone.

Establishing and maintaining ICZM provides the following advantages for the coastal areas:

1. Creating balance between existing and future exploitations in the coastal zone;

2. Preserving the coastal ecological resources;

3. Protecting human communities against natural hazards;

4. Preventing environmental pollution;

5. Making ground for economic growth in the framework of sustainable development.

ICZM is a complex and continuous process. It is also a time-consuming affair with respect to planning and implementation. It requires much capacity building and preparing the ground for public participation over a period of time.

Any attempt to implement ICZM must enjoy legitimacy which can only be obtained by respecting the laws as well as the customs and cultural traditions of the place where it is to be implemented.

In case of small islands, however, each of the issues mentioned in Table 1, with various degrees of importance, cause major difficulties in the process of establishment of an integrated coastal management. Although the main elements of a good ICZM practice are available based on the past experiences, there are varying levels of progress in putting these elements into practice and creating sustainable outcomes. The examples for weaknesses that detract from the potential effectiveness of ICZM include [4]:

1. Low levels of involvement of the private sector in ICZM processes;

2. Weak integration of spatial, economic, and environmental planning between the terrestrial and marine components; 
3. Lack of tools for effective implementation of coastal planning;

4. Gap between the expertise of central and local governments regarding ICZM. Usually, the central or provincial authorities have strong technical and financial capabilities and local authorities are sometimes weak and not familiar with ICZM concepts and practices;

5. Poor cooperation and weak coordination between sectoral agencies that can inhibit vertical and horizontal integration of policies, plans, and management strategies affecting coastal areas;

6. Lack of understanding of natural and man-induced hazards in coastal areas and the way they might increase as a result of global change.

\section{ICZM in Iran}

Iran is one of the signatories of the UN convention and has initiated ICZM efforts since 2002. Ports and Maritime Organization of Iran along with 18 marinerelated state bodies started the ICZM study project in 7 provinces (3 provinces along the southern Caspian Sea coastlines and 4 provinces along the coastlines of Persian Gulf and Oman Sea). The first and second phases of this study took around 6 years to finish; then, synthesis of the results and ratification of the outcomes by the authorities lasted until 2012. Establishment of ICZM in Iran's coastal provinces was started in 2013 and Hormozgan province was selected for this pilot endeavor.

On the other hand, some of the islands started their ICZM initiatives earlier. As mentioned above, islands with environmental sensitivities and vulnerabilities require special attention. Kish, a small island in the Persian Gulf around $18 \mathrm{~km}$ far from the main land, can be considered as a pioneer in integrated coastal zone management in Iran. As a free trade zone, Kish Island has been under different kinds of pressures that lead to deteriorating environmental standards and pollution. Kish authorities soon realized that the island's problems call for a holistic and integrated approach to management that harmonizes the activities in and around the island. Free Trade Zones (FTZs) around the world have special characteristics. They offer advantages of free import/export of goods that attract the investors to the region and boost the regional economy. Application of ICZM concepts and methods in FTZs requires a good deal of sophistication. In FTZs, ICZM is responsible for nature conservation, minimization of the conflicts among the stakeholders, and harmonizing the terrestrial and marine activities; also, it should integrate spatial and economic development planning [4]. Establishment of an integrated management in FTZs is influenced by the advantages or disadvantages mentioned in Table 2. In Kish, the common problems of small islands and complications arising from the free trade activities have rendered the ICZM as the only tool that can pave the way for island's resiliency.

\section{Kish Island characteristics}

Kish is a small island in the north of the Persian Gulf region with about $91 \mathrm{~km}^{2}$ of surface area and $35 \mathrm{~km}$ of perimeter. It is a relatively flat coral island with a maximum height of $45 \mathrm{~m}$ above the sea level. The island is located $18 \mathrm{~km}$ south of the mainland with a distance of $250 \mathrm{~km}$ west of the strategic strait of Hurmoz (Figure 1). Hurmoz strait is the bottle neck of the oil stream from the huge oil and gas reserves of the Persian Gulf region towards the rest of the world. The number of the vessels that crossed this strait in 2006 exceeded 15000 ships, carrying around $45 \%$ of the world's oil/gas consumption. This large figure of

Table 2. Advantages and disadvantages of FTZs for implementation of ICZM plans.
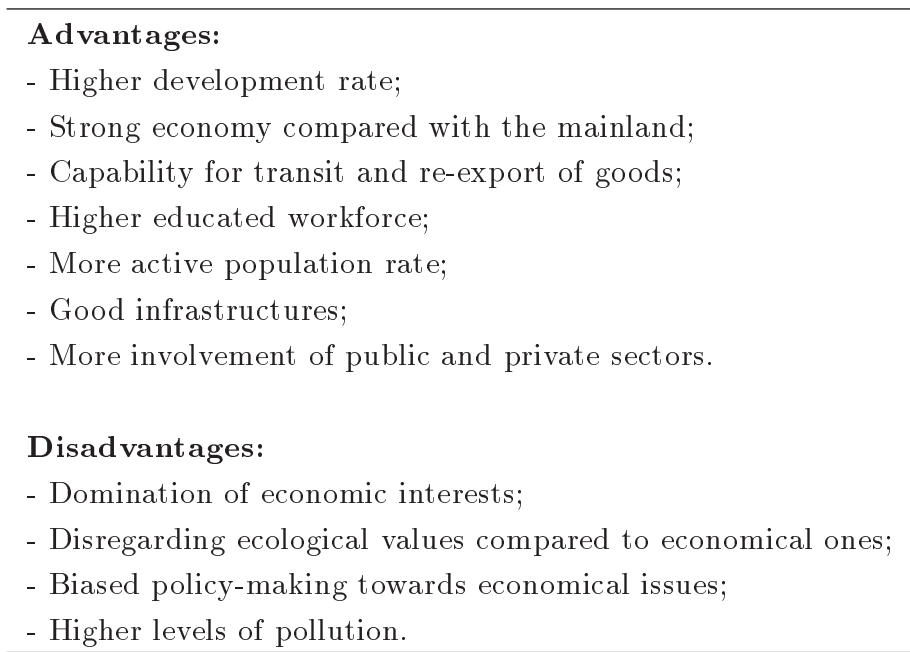

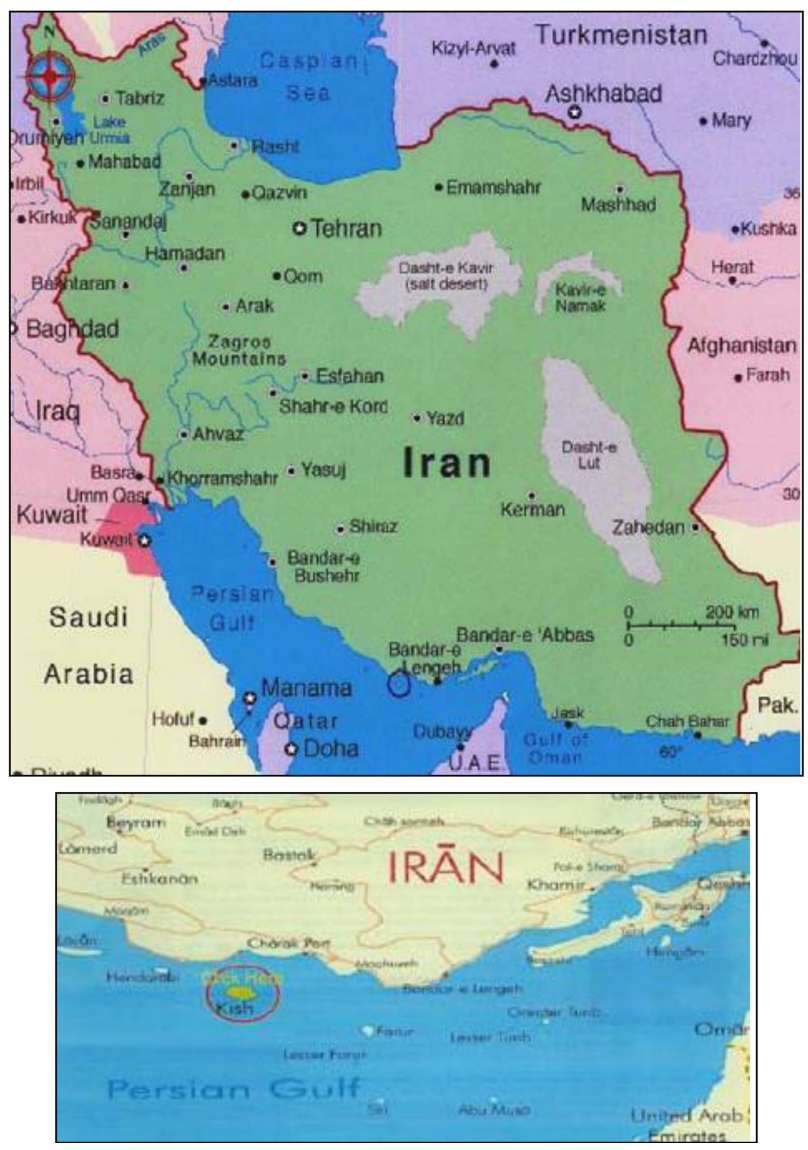

Figure 1. Location of Kish Island in Persian Gulf.

the seaborne transportation is a basic threat to the marine environment due to the considerable volume of pollution.

Persian Gulf is a closed body of water with a maximum depth of $65 \mathrm{~m}$, which connects its littoral states to open seas solely through Hurmoz strait. It has a unique hydraulic regime. It has been estimated that the water of this Gulf can be changed once in a 40year time period. This is because its inlets and outlets are very small compared with the volume of water that it normally contains. The occurrence of two wars in this strategic region during the last two decades and the amount of pollutants that were either poured or dumped into the sea during the wars, as well as the oil tankers that have been drowned in the sea, have caused severe harms to the Persian Gulf environment. To restore the situation, the Persian Gulf littoral states have already started a joint effort by establishing a regional organization called ROPME (Regional Organization for Protection of Marine Environment) that was formed after the Kuwait convention (1992) [5].

Although Persian Gulf has suffered from two major wars in the last two decades, the marine environmental problems have mostly occurred along the southern and western borders and the Northern coastlines do not seem to bear the burden of an environmental disaster as much as it was previously expected. The coastlines of Kish Island are no exception and its beautiful marine nature and attracting beaches, which are unique in the Persian Gulf region, did not suffer much from the past incidents. Kish Island was declared a 'free trade zone' by the government in 1989 .

Kish population in 1998 was 16600 , which reached to 22000 in 2003 , showing a $5 \%$ annual increase. This rapid immigration rate has mostly been due to very good employment opportunities that were the result of the free trade policies of the central government in order to boost the regional economy and reduce high unemployment rate of the country. A recent study has estimated that Kish population will reach 85500 in the year 2025 [6].

Kish is the destination of around 800,000 domestic tourists every year that come to the island for spending their vacations. Although in only 6 months of the year the weather permits outdoor activities such as sports and recreation, the retailers and other service providers have been successful in attracting tourists even during the hot months of summer. Kish has a warm and humid weather during spring and summer, and a mild and pleasant weather during fall and winter. Its average maximum monthly temperature is 33.9 and average minimum monthly temperature is 18.6. Kish has several shopping malls, a multitude of luxurious hotels, recreation centers, and sea-sport clubs. Sight-seeing and cycling are popular activities in the coastal areas due to a good wealth of natural values that the island exhibits. On the terrestrial side, the habitat for 120 different types of birds, animals, and also unique types of sea-turtles attracts many people. In the marine side, corals, sponges, and marvelous types of reef fish provide an excellent opportunity for ecotourism and activities such as scuba diving [7].

In Kish, the proportion of the active population is $70 \%$, while the same figure for the mainland does not exceed $37 \%$. Table 3 shows the distribution of the active workforce for different activities in Kish Island. Also, in this table, the percent that each activity contributes to the island's GDP is presented.

Kish Island is governed by Kish Free Zone Organization. The managing director of KFZO is selected by the country's Free Trade Zones Higher Council (FTZHC), which operates under supervision of the vice-president. Although KFZO should observe the country's general laws and regulations, it is almost autonomous inside the island territories and all the authorities and responsibilities of the government have been transferred to KFZO.

Kish can be compared with Malt Island in the Mediterranean Sea. The geographic-strategic, natural, and ecological situations as well as populations of these two islands are similar. Trade and tourism histories of these islands are also alike [6]. 
Table 3. Importance of different human activities in Kish Island.

\begin{tabular}{lcc}
\hline \multicolumn{1}{c}{ Activity } & Work-force GDP \\
& \% & $\%$ \\
\hline Agriculture & 0.1 & 0.03 \\
Fisheries & 1.62 & 0.16 \\
Mining & 0.34 & - \\
Industry & 8.04 & 5.49 \\
Energy sector & 2.42 & 6.35 \\
Construction & 18.82 & 2.53 \\
Retail & 24.27 & 29.11 \\
Hotel restaurant & 8.99 & 7.71 \\
Transportation and communication & 8.50 & 6.15 \\
Dealership & 2.14 & 2.36 \\
Renting & 5.09 & 16.33 \\
Public works & 5.24 & 19.66 \\
Education & 2.63 & 0.50 \\
Health and social welfare & 0.70 & 0.87 \\
Other & 10.6 & 2.75 \\
Total & 99.54 & 100 \\
\hline
\end{tabular}

\section{Existing problems and initiation of ICZM}

The problems that the island has currently faced have shown a rising trend in recent years. These problems originate in different natures, with most of them being somehow related to environmental issues, problems regarding legislation, land-use, and tourism. Table 4 contains a list of the problems [8].

KFZO started the integrated coastal management study, aiming to create a balance between the existing contradictory needs for development, to minimize the conflicts and alleviate the pressures that are exerted on the island's environment.

In the course of Kish ICZM study, based on the facts and information gathered from a comprehensive database and Geographic Information System (GIS), and by evaluating the needs of the KFZO to pave the way for the establishment of a sustainable management, four strategic plans were prepared:

1. Environmental management plan;

2. Shoreline management plan;

3. Monitoring and evaluation plan;

4. Desired land-use plan.

The first management plan is expected to conserve the terrestrial and marine ecosystems (e.g., corals, reef fish, turtles, etc.), restore the damaged habitats, and provide the required control measures for the sea-water as well as soil, groundwater, and air pollutants.
The second management plan basically pertains to the engineering measures that should be applied by the authorities to protect the shoreline from undesirable erosion and/or accretion of the sediments and also to build structures that are required against coastal flooding.

The third plan is intended to serve the need for measurement and recording of the basic physi$\mathrm{cal} / \mathrm{chemical} /$ biological indicators in the coastal areas and monitoring of the changes and trends that may threat island's environment and inhabitants. This plan also helps the authorities to evaluate the effectiveness of different plans and projects that are carried out in the framework of integrated coastal management and examine the level of success of ICZM.

Due to the importance of the economical issues in FTZs and the necessity of fulfilling the expectations of the investors in a competitive way, and also due to the lack of law or inadequate law enforcement in the island, it was found that 'spatial planning' could be very instrumental in implementation of the integrated management. Responding to the needs of Kish FTZ necessitates the valuable coastal land to be wisely managed and well allocated to different beneficiaries in order to establish a balance among different activities. This allocation must also observe the environmental sensitivities and preservation of sensitive habitats in the islands' terrestrial and marine zones. It was found that achievement of the ICZM goals in the island would not be possible without a land-use plan. The desired land-use plan serves as a tool for a harmonious and target-oriented management that provides the ground for establishment of integration among different activities in the island. The general methodology of ICZM studies in Kish Island is illustrated in Figure 2.

\section{Strategic management plans}

\subsection{Environmental management plan}

Preparation of an environmental management plan requires a deep understanding of the situation and identification of current and future problems. The ecological and human environments have been thoroughly studied by field operations as well as desk studies and the results have been loaded on a comprehensive GIS database. Based on the obtained results, the following plans have been provided:

- Management plan for protection of sensitive ecological regions;

- Management plan for rehabilitation of destructed habitats;

- Management plan for solid waste disposal;

- Management plan for liquid waste/waste water disposal; 
Table 4. Existing problems in Kish free trade zone.
a) Legislation
- Violation of set-back line regulations and illegal construction;
- Lack of laws and regulations for controlling coastal activities;
- Inconsistent management and policy-making;
- Real state problems in the coastal areas.

b) Environment

- Municipal/industrial solid waste disposal;

- Watewater/sewage disposal;

- Oil pollution in the coastal areas;

- Ground water contamination;

- Destruction/threatening of marine and terrestrial habitat;

- Destruction of natural and beautiful landscapes.

c) Coastal land-use

- Existing illegal and/or unsuitable structures (e.g. scattered jetties);

- Unplanned development in the coastal area;

- Problems associated with commercial and fishing ports;

- Lack of public recreational facilities in the coastal areas;

- Problems associated with water-intakes and sea-water desalination plants.

d) Infrastructure

- Inadequate water supply;

- Power shortage;

- Fuel;

- Communication.

\section{e) Tourism}

- Lack of suitable swimming beaches;

- Problems associated with coastal and marine recreational activities;

- Coastal villages and coastal parks;

- Cultural problems.

- Management plans for air pollution.

In preparation of the environmental management plan, the ecological capacity of terrestrial and marine areas have been evaluated. One of the major outcomes of the environmental management plan was allocation of an area in the south-east of the island for a new "National Park" due to its unique natural resources, especially sea turtles.

\subsection{Shoreline management plan}

The development of the human activities in the coastal zone is strongly related to the development of coastal protection and construction of flood protection structures, e.g. dwelling mounds, dykes, groins, etc. This plan plays a major role in physical stability and resiliency of the island. Generally, common technical measures for shoreline protection include [9]:
- Beach nourishment;

- Groin fields;

- Offshore breakwaters;

- Artificial reefs;

- Submerged offshore breakwaters.

In the course of preparation of this plan, wind, wave, currents, tides, surges, and also long-shore and cross-shore sedimentation regimes around Kish Island have carefully been studied. Then, based on the obtained results, coastal cells and sub-cells have been identified and proper shoreline management measures have been proposed.

\subsection{Monitoring and evaluation plan}

The preparation of this management plan had a twofold objective. First, for the developing countries where 


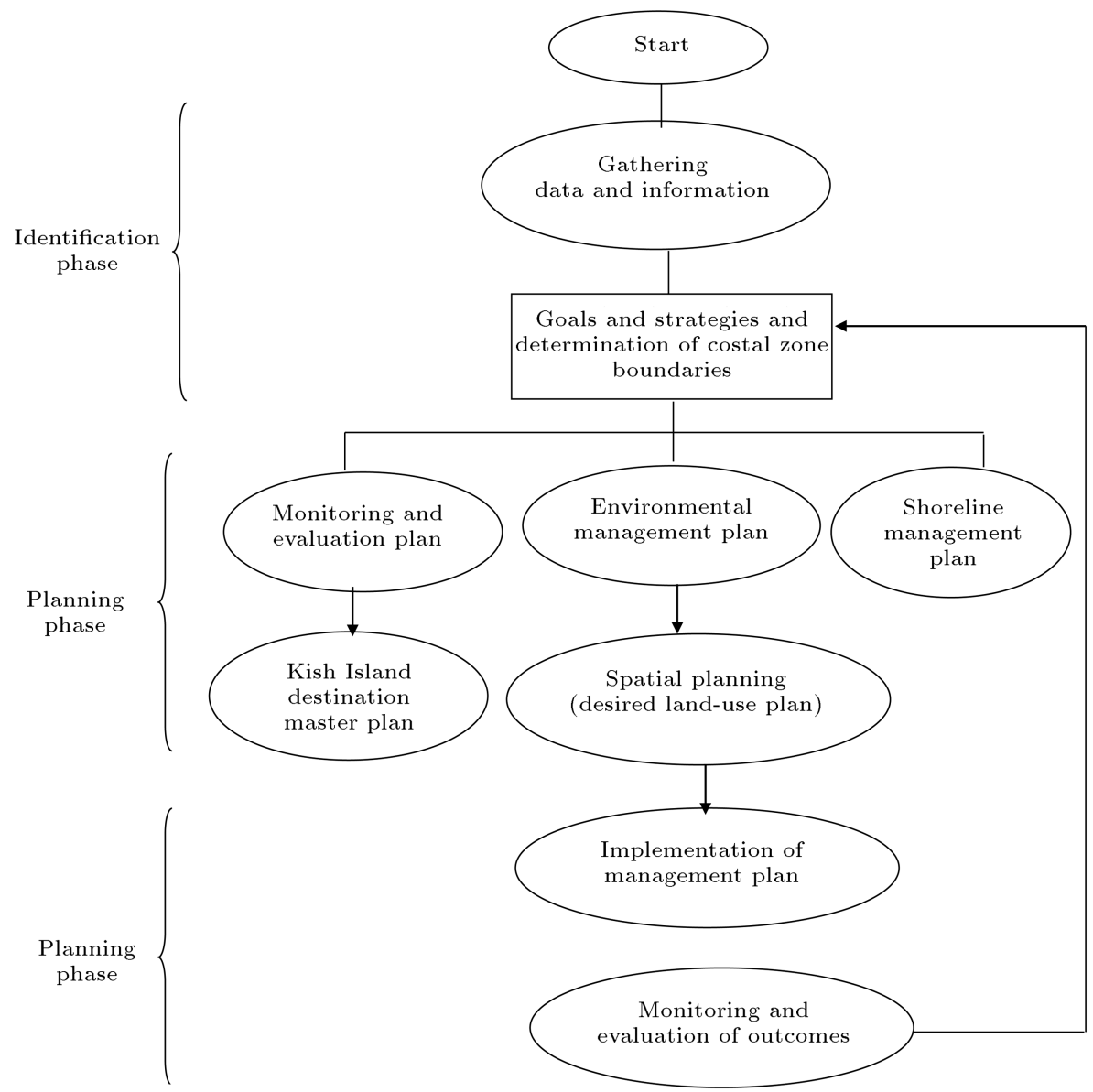

Figure 2. Kish ICZM study and implementation procedure.

the necessary long-term data and statistics for scientific studies are hardly available, the monitoring and evaluation plan provides a clear framework and timetable for the authorities to establish data recording and monitoring stations for gathering necessary physical, chemical, biological, and other ecological and engineering data. Second, evaluating the level of success of the ICZM plan (that requires recognizing the constraints and pitfalls and employing appropriate means in order to modify future actions related to ICM plan) can be carried out using the monitoring and evaluation plan.

\subsection{Desired land-use plan}

Desired land-use plan will be discussed in the next section in more detail.

\section{Spatial planning approach for integration}

Setting up an administration or establishing an organization does not necessarily guarantee the success of an ICZM plan. Implementation is the most crucial phase, since the global experience has shown that ICZM faces real challenges in the execution phase.

The strong business orientation in FTZs necessitates the rules and regulations that originate in
ICZM planning finding realistic grounds to be observed by various stakeholders. As mentioned, the spatial planning approach is employed as a management tool to guarantee, as much as possible, the success of the integrated management plan at the coastal areas. It should be emphasized, however, that solely implementing a desired land-use plan in a very strict way can not necessarily assure the authorities for sustainable management. In other words, spatial planning should not be considered as a 'goal' but a 'means' for better integration.

The role of 'spatial planning' within ICZM strongly depends on the fundamental understanding of ICZM either as a planning and decision-making tool or as a holistic philosophy of thought [10]. Although spatial planning has already been of concern in some ICZM plans (e.g., German National ICZM plan [11]), employing spatial planning as the pivot for implementation of other strategic plans that are required for sustainable management in the coastal zone of free trade zones does not seem to gain the attention that it deserves.

A number of tools and techniques already exist and are available for implementation within an integrated coastal zone management framework. Some 
of the more frequently used management techniques include:

- Zonation: The coastal area is divided into geographical zones for management purposes. The zone can be determined based on distances, height above sea level, degree of risk to storm surges, etc.;

- Set-back lines and exclusionary zones: Line along the shoreline beyond which construction of a building is prohibited, usually to keep structures out of the areas where coastal erosion can cause damage or where there may be hazardous or sensitive zones;

- Protected areas: Areas of land or water that have been specially designated to protect some aspect of flora, fauna, habitat, or ecosystem, usually for the protection of rare and endangered species;

- Special area planning: Where it is important to plan and manage an area as an entire unit;

- Acquisition, easement, and development rights: The method through which the government is able to control the use of particular pieces of coastal land through purchase;

- Coastal permits: The enacted law that requires anyone who wishes to undertake an activity in the coastal zone to obtain a permit from the appropriate agency.

These techniques have been employed in preparation of a spatial umbrella plan for implementing other management plans and integrate various stakeholders' objectives under the authority of KFTZ. For Kish Island, the results obtained from four different disciplines, namely morphology, hydrodynamics, ecology, and existing land-use that were conducted by SPI consulting engineers, have been used in preparation of the desired land-use plan. Thematic studies were carried out and the results were gathered in a geographical information database. Table 5 shows the maps and information that were used.
General categories of land-use in the Kish coastal area are tourism, ecotourism, sea sports, residential, aquaculture, public services, and infrastructure.

For land-use planning of the coastal zone, two relatively independent methods were used. In the first method, different study groups reported land suitability for various activities based on the results that were obtained in thematic studies. These reports on land suitability were then combined and the desired land-use plan was obtained from the synthesis of the various viewpoints of disciplines. In this method, firstly, sedimentation/erosion cells and sub-cells around the island were identified based on coastal engineering studies and the relevant activities for each sub-cell were introduced. In the second phase, these sub-cells were studied by the environmental group to distinguish the environmental sensitivities and ecological values of each sub-cell and to apply the necessary filtering on the unsuitable activities. In the last step, the proposed land-uses were checked out for compatibility with the existing land-uses.

The second method was a GIS-based method. Generally, Boolean, Fuzzy, and Index overlay methods are common methods that are used for this purpose in a GIS environment. In the Kish ICZM study, an index overlay method with the multi-class map has been used. In index overlay method, every map has a weight in the procedure of land-use planning and each information layer is assigned a value according to a specific activity. In this way, a table of weights is prepared for each map and then a matrix of the assigned scores for each activity is provided. The average of the scores is calculated based on the following relation:

$$
\bar{S}=\frac{\sum_{i=1}^{n} S_{i j} * w_{i}}{\sum_{i=1}^{n} w_{i}},
$$

where $\bar{S}$ is the average score, $w_{i}$ the weight for the $i$ th map, and $S_{i j}$ the score of the $j$ th layer embedded in the $i$ th map. The weights of the maps with respect to the land-uses used in this study are shown in Table 6 .

Table 5. Maps and information used in spatial planning.
- Coastal morphology:
1) Erosion and sedimentation zoning map;
2) Sea-bottom sediment typology map;
3) Sea-bottom terrain and slope map;
4) Landforms along the beach.

- Ecology and environment:
1) Corals distribution map
2) Turtle habitat map;
3) Bird habitats map;
4) Sea-grass zonation map.

- Coastal hydrodynamics:

1) Coastal flooding map;

2) Sea-wave height zonation map;

3) Sea-current speed zonation map;

4) Wave-energy zonation map.
- Existing land-use:
1) Existing land-use map;
2) Proposed (future) land-use map;
3) Real state (ownership) map. 
Table 6. Weight of the maps for different land-uses in the coastal zones.

\begin{tabular}{|c|c|c|c|c|c|c|c|c|c|c|}
\hline & & & Tourism & Eco. ${ }^{a}$ & $\begin{array}{c}\text { Sea } \\
\text { sports }\end{array}$ & $\begin{array}{c}\text { Industry } \\
\& \\
\text { infrastructures }\end{array}$ & Aquaculture & Commercial & Resi. ${ }^{b}$ & $\begin{array}{c}\text { Urban } \\
\text { services }\end{array}$ \\
\hline \multirow{4}{*}{ 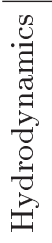 } & 1 & Flooding & 0.6 & 0.7 & 0.6 & 0.7 & 0.5 & 0.5 & 0.9 & 0.9 \\
\hline & 2 & Sea-waves height & 0.3 & 0.5 & 0.7 & 0.7 & 0.5 & 0.5 & 0.7 & 0.5 \\
\hline & 3 & Tidal currents & 0.1 & 0.4 & 0.8 & 0.4 & 0.6 & 0.6 & 0.2 & 0.1 \\
\hline & 4 & Sea-wave energy & 0.2 & 0.4 & 0.8 & 0.6 & 0.5 & 0.4 & 0.4 & 0.4 \\
\hline \multirow{4}{*}{$\begin{array}{l}\overrightarrow{0} \\
0 \\
0 \\
\frac{0}{0} \\
\frac{1}{2} \\
\frac{0}{2}\end{array}$} & 5 & $\begin{array}{c}\text { Erosion/ } \\
\text { sedimentation }\end{array}$ & 0.3 & 0.4 & 0.7 & 0.6 & 0.6 & 0.5 & 0.7 & 0.5 \\
\hline & 6 & $\begin{array}{l}\text { Sea-bottom } \\
\text { terrain }\end{array}$ & 0.1 & 0.4 & 0.7 & 0.3 & 0.6 & 0.5 & 0.1 & 0.1 \\
\hline & 7 & $\begin{array}{l}\text { Sea-bottom } \\
\text { slope }\end{array}$ & 0.2 & 0.3 & 0.8 & 0.5 & 0.5 & 0.4 & 0.2 & 0.2 \\
\hline & 8 & Beach & 0.6 & 0.6 & 0.7 & 0.5 & 0.3 & 0.4 & 0.7 & 0.6 \\
\hline \multirow{5}{*}{ 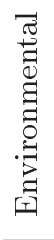 } & 9 & Corals & 0.8 & 1.0 & 0.8 & 0.9 & 0.8 & 0.7 & 0.5 & 0.4 \\
\hline & 10 & Turtle habitats & 0.7 & 0.9 & 0.9 & 0.9 & 0.8 & 0.8 & 0.8 & 0.9 \\
\hline & 11 & IUCN birds & 0.6 & 1.0 & 0.7 & 0.8 & 0.6 & 0.4 & 0.7 & 0.6 \\
\hline & 12 & Sea-weeds & 0.2 & 0.7 & 0.6 & 0.5 & 0.7 & 0.6 & 0.3 & 0.2 \\
\hline & 13 & Marine & 0.3 & 0.8 & 0.7 & 0.8 & 0.8 & 0.6 & 0.5 & 0.2 \\
\hline
\end{tabular}

${ }^{\mathrm{a}}$ Eco.: Ecotourism; ${ }^{\mathrm{b}}$ Resi.: Residential.

The score of each information layer is assigned based upon the suitability with respect to a certain activity. The score ranges between 1 (most suitable) and 10 (least suitable). The total suitability of a region for an activity is determined by taking the average of the weights in GIS and using a histogram of frequencies. The suitability of each region has been identified as suitable (S1), relatively suitable (S2), and not suitable $(\mathrm{N})$. Intersection of the obtained map above with the map delineating the sub-cell regions yielded the desired spatial plan in this method. Comparing two spatial plans obtained from two methods demonstrated that in $77 \%$ of the coastal areas, the proposed land-uses from two methods were the same. This indicated that the basic studies that were conducted and the used methods were reliable and compatible.

The final land-use plan was provided by combining the outcomes of the two methods mentioned above (Figure 3 ). This spatial plan integrates all three management plans that were prepared during Kish ICZM studies. This plan enables the authorities to distinguish the most important priority in issuing the permissions for various activities and to settle down the issues that usually arise in allocating coastal lands among different stakeholders (private sector, coastal authorities, and Department of the Environment) and paves the way for converging various activities towards a sustainable and harmonized development. A detailed description of the methodology used for this study can be found in the reports of the Integrated Coastal Management Plan of the Kish Island conducted by SPI consulting engineers [12].

\section{Concluding remarks}

Integrated coastal zone management for Kish Island, a free trade zone, has been described in this paper. The methodology of the study and the management plans that were deemed necessary for reducing the level of pressure faced by the island and minimizing the conflicts among the stakeholders, and also measures for preservation of the sensitive environment of the island in the strategic situation of Persian Gulf, have been explained.

Vulnerability and low level of resiliency of small islands cause different kinds of problems, such as loss of lives and properties, deterioration of the living conditions for the inhabitants, diminished biodiversity, and degradation of environmental conditions in these areas, which should properly be addressed in ICZM initiatives. Despite the fact that in recent ICZM attempts in some countries, less restrictive practices are recommended for implementation of management plans in the coastal zones, it is found here that due to strong economical concerns that exist in 'free trade zones,' taking a spatial planning approach plays an important role in achieving the goals and objectives of ICM. 


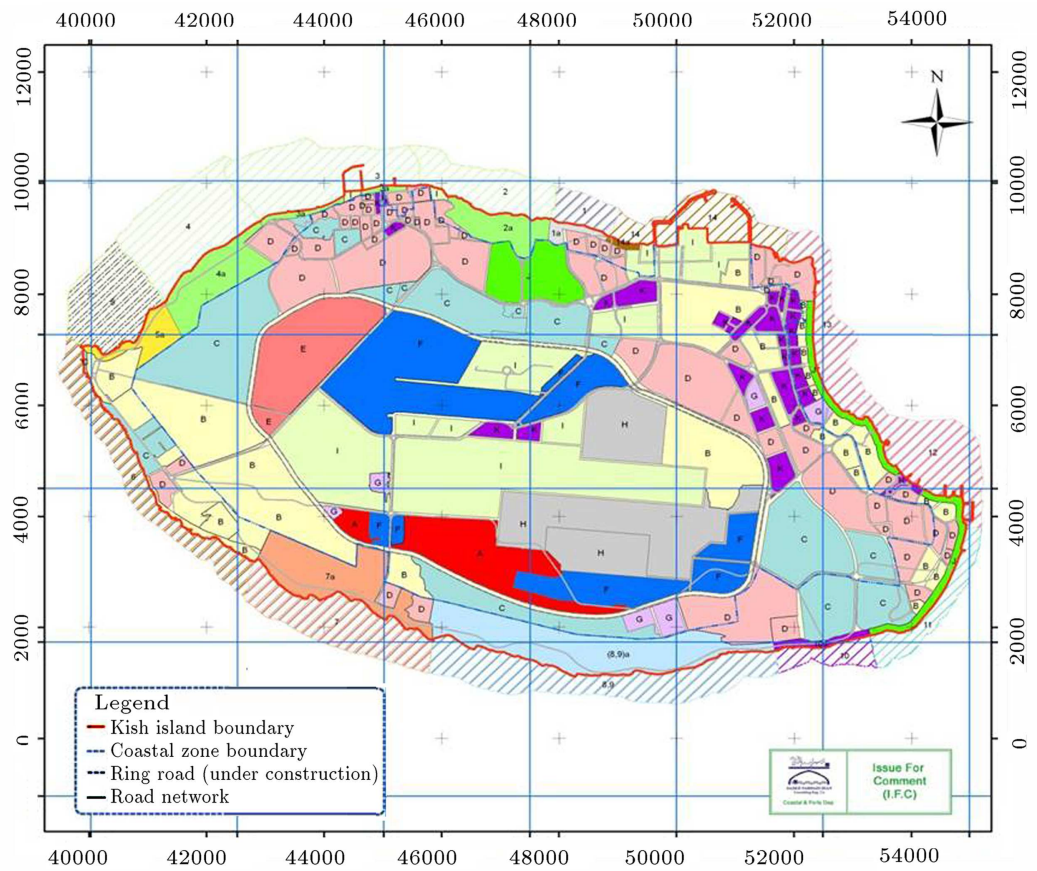

\begin{tabular}{|c|c|c|c|c|c|c|}
\hline \multicolumn{7}{|c|}{ Land-use prioritization } \\
\hline Remarks & $\begin{array}{c}\text { Land use } \\
\text { with detailed } \\
\text { EIA }\end{array}$ & $\begin{array}{c}\text { Land use } \\
\text { with preliminary } \\
\text { EIA }\end{array}$ & $\begin{array}{l}\text { Recommended/ } \\
\text { permitted } \\
\text { land use }\end{array}$ & Color & $\begin{array}{l}\text { Sub- } \\
\text { zone }\end{array}$ & 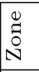 \\
\hline- & Other & Aquaculture & $\begin{array}{c}\text { Ecotourism } \\
\text { water sports }\end{array}$ & $\ddot{c}$ & $\begin{array}{c}1 \\
1 \mathrm{a} \\
\end{array}$ & \\
\hline- & $"$ & Tourism & $\begin{array}{l}\text { Ecotourism } \\
\text { water sports }\end{array}$ & \& & $\begin{array}{c}2,3,4 \\
2 \mathrm{a}, 3 \mathrm{a}, 4 \mathrm{a}\end{array}$ & \\
\hline- & " & Tourism & Ecotourism & 学 & \begin{tabular}{|c|}
5 \\
$5 \mathrm{a}$ \\
\end{tabular} & \\
\hline- & “ & $\begin{array}{c}\text { Tourism } \\
\text { water sports }\end{array}$ & Ecotourism & \% & 6 & \\
\hline- & " & $\begin{array}{c}\text { Tourism } \\
\text { residential/office }\end{array}$ & Ecotourism & $\ddot{3}$ & $\begin{array}{c}7 \\
7 \mathrm{a} \\
\end{array}$ & : \\
\hline - & - & - & $\begin{array}{l}\text { National } \\
\text { park }\end{array}$ & $\dot{\sim}$ & $\begin{array}{c}8,9 \\
8 \mathrm{a}, 9 \mathrm{a}\end{array}$ & $\frac{\pi}{0}$ \\
\hline $\begin{array}{l}\text { Industry and } \\
\text { infrastructure } \\
\text { not permitted }\end{array}$ & Other & $\begin{array}{l}\text { Residential/ } \\
\text { office } \\
\text { aquaculture }\end{array}$ & Ecotourism & 赵 & $\begin{array}{l}10 \\
10 \mathrm{a}\end{array}$ & $\circlearrowright^{\pi}$ \\
\hline “ & $\begin{array}{c}\text { Water sport } \\
\text { residential/office }\end{array}$ & Ecotourism & - & as & 11 & \\
\hline- & Other & $\begin{array}{c}\text { Residential/ } \\
\text { office }\end{array}$ & $\begin{array}{l}\text { Water sports } \\
\text { ecotourism }\end{array}$ & $\alpha$ & $\begin{array}{l}12, \\
13\end{array}$ & \\
\hline- & $\begin{array}{c}\text { Infrastructure } \\
\text { other }\end{array}$ & Aquaculture & $\begin{array}{l}\text { Residential/ } \\
\text { office }\end{array}$ & $\Leftrightarrow$ & $\begin{array}{c}14 \\
14 \mathrm{a}\end{array}$ & \\
\hline- & Industry & $\begin{array}{l}\text { Residential/ } \\
\text { office }\end{array}$ & $\begin{array}{c}\text { Tourism } \\
\text { ecotourism }\end{array}$ & ๘ & A & \\
\hline “ & Other & $\begin{array}{c}\text { Residential } \\
\text { office }\end{array}$ & $\begin{array}{l}\text { Ecotourism } \\
\text { tourism }\end{array}$ & $\varpi$ & B & \\
\hline " & Other & $\begin{array}{c}\text { Tourism residential/ } \\
\text { office }\end{array}$ & Ecotourism & $\mathrm{es}$ & $\mathrm{C}$ & \\
\hline $\begin{array}{l}\text { Industry not } \\
\text { permitted }\end{array}$ & - & Other & $\begin{array}{l}\text { Residential/ } \\
\text { office (Mixed) }\end{array}$ & $\infty$ & $\mathrm{D}$ & \\
\hline - & Industry & $\begin{array}{l}\text { Residential/ } \\
\text { office }\end{array}$ & Ecotourism & 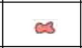 & $\mathrm{E}$ & \\
\hline - & - & Industry & $\begin{array}{c}\text { Residential/ } \\
\text { office tourism }\end{array}$ & $\infty$ & $\mathrm{F}$ & $\Xi$ \\
\hline $\begin{array}{c}\text { Municipal/industry } \\
\text { not permitted }\end{array}$ & $\begin{array}{l}\text { Tourism } \\
\text { other }\end{array}$ & - & Ecotourism & 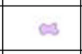 & G & 告 \\
\hline $\begin{array}{c}\text { Based on } \\
\text { Kish destination } \\
\text { master plan }\end{array}$ & - & - & $\begin{array}{l}\text { Reserved } \\
\text { area }\end{array}$ & $\infty$ & $\mathrm{H}$ & $\frac{\check{L}^{\circ}}{\Xi}$ \\
\hline $\begin{array}{l}\text { Industry outside } \\
\text { the ring-road } \\
\text { not permitted }\end{array}$ & - & $\begin{array}{l}\text { Industry/ } \\
\text { infrastructure }\end{array}$ & - & 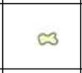 & I & \\
\hline $\begin{array}{c}\text { Industry not } \\
\text { permitted }\end{array}$ & - & Other & Sports & $\infty$ & $\mathrm{J}$ & \\
\hline \multirow[t]{2}{*}{-} & - & - & $\begin{array}{l}\text { Mixed land } \\
\text { use }\end{array}$ & $\omega$ & K & \\
\hline & & & $\begin{array}{c}\text { Read } \\
\text { Network }\end{array}$ & $\bar{c}$ & & \\
\hline \multicolumn{5}{|c|}{\begin{tabular}{|l} 
Client: Kish Free Zone Organization (KFZO) \\
\end{tabular}} & & \\
\hline \multicolumn{5}{|c|}{ Project management: Fara darya arsheh } & & \\
\hline \multicolumn{5}{|c|}{$\begin{array}{l}\text { Consultant: Sazeh Pardazi Iran (SPI) } \\
\text { (Coasts, Ports and marine structures department) }\end{array}$} & & \\
\hline & & & \\
\hline & & & & & & \\
\hline \multicolumn{4}{|c|}{\begin{tabular}{|l|} 
Coordinate system: KTMP (Map system: TM) \\
Scale: \\
\end{tabular}} & & & \\
\hline
\end{tabular}

Figure 3. Kish FTZ land-use plan. 
For Kish Island Free Trade Zone, the ICZM studies indicate that four strategic plans, i.e. environmental management plan, shoreline management plan, monitoring and evaluation plan, and desired landuse plan are necessary for implementing the integrated coastal zone management and increasing the level of resiliency of the island.

\section{Acknowledgement}

The authors wish to thank Kish Free Zone Organization (KFZO) and Sazeh Pardazi Iran (SPI) consulting engineers for their support and granting permission for preparing this paper.

\section{References}

1. Burbridge, P.R. "A critical review of progress towards Integrated coastal Management in Baltic sea Region", Coastline Reports 2 in Managing the Baltic Sea, G. Schemeski \& N. Loser, Eds. (2004).

2. United Nations, Barbados Programmer of Action, First Global Conference on the Sustainable Development of SIDS, Barbados (1994).

3. Kaly, U., Pratt, C. and Howorth, R. "Towards managing environmental vulnerability in small islands developing states (SIDS)", SOPAC Miscellaneous Report, 461(16) (2002).

4. Kerr, S.A. "What is small island sustainable development about?", Ocean and Coastal Management, 20(78), pp. 503-524 (2005).

5. http://www.ropme.com/

6. Drees and Sommer Co. "Kish island destination master plan (Persian Garden in Persian Gulf)", Final Report, 1 (2005).

7. Sazeh Pardazi Iran (SPI) Consulting Engineering Company "Current environmental status of Kish Island (Volume I)", Kish Island ICZM Study Project Reports (2008).

8. Pak, A. and Majd, F. "Integrated coastal management plan in free trade zones, A case study", Ocean \& Coastal Management, 54, pp. 129-136 (2011).

9. Frohle, P. and Kohlhase, S. "The role of coastal engineering in integrated coastal zone management",
Coastline Reports 2 in Managing the Baltic Sea, G. Schemeski and N. Loser, Eds. (2004).

10. Olsen, S., Lowry, K., Tobey, J., Burbridge, P.R. and Humphrey, S. "Current purposes and methods for evaluating coastal management projects and programs funded by international donors", Coastal Management Report No. 2200, Coastal Resource Center, University of Rhode Island (1998).

11. Geek, K., Kannen, A., Glaeser, B. and Sterr, H. "National ICZM strategies in Germany : A spatial planning approach", Coastline Reports 2 in Managing the Baltic Sea, G. Schemewski and N. Loser, Eds. (2004).

12. Sazeh Pardazi Iran (SPI) Consulting Engineering Company "Integrated coastal management plan of Kish Island", Reports of the study conducted for KFZO (2008).

\section{Biographies}

Ali Pak is Professor of Civil Engineering at Sharif University of Technology. He has several articles regarding the engineering aspects of dredging and coastal structures. Other than his main specialty, he has been responsible for a number of studies on the topic of Integrated Coastal Zone Management (ICZM) in the coastal provinces of Iran and has published ICZMrelated papers in internationally accredited journals and conferences.

Farhad Majd is the Head of the Coasts and Marine Structures Department of the Sazeh Pardazi Iran (SPI) Consulting Engineering Company. As a mechanical engineer, he has obtained his Master's degree in Coastal Engineering from IHE Delft. He has been in charge of the design and construction supervision of several ports and marine structures. He has also been heavily involved in Iran's national project of ICZM plan and also in Kish Island ICZM project.

Maryam Mohammadi is the Head of the Environment Bureau of the "Civil and Infrastructures" deputy of Kish Free Zone Organization (KFZO). She has a Master's degree in Environmental Science. She has been instrumental in implementation of the integrated management along the coasts of Kish Island. 